\title{
Novel clinical and morphological predictors of malignancy in patients with ovarian endometrioid cysts
}

\author{
L.M. Mikhaleva', O.I. Patsap', T.V. Bezuglova', A.I. Davydov', G.M. Aliev ${ }^{1,3,4}$ \\ ${ }^{1}$ Research Institute of Human Morphology, Moscow, Russia \\ ${ }^{2}$ Federal Center of Brain Research and Neurotechnologies of the Federal Medical Biological Agency, Moscow, Russia \\ ${ }^{3}$ I.M. Sechenov First Moscow State Medical University (Sechenov University), N.V. Sklifosovsky Institute of Clinical Medicine, \\ Moscow, Russia \\ ${ }^{4}$ GALLY International Research Institute, San Antonio, TX, USA
}

\begin{abstract}
Introduction. Endometriosis is an endless source of scientific investigations, but still the mechanisms of malignant transformation of ovarian endometriosis remain to be understood.

Patients and methods. This study was conducted on surgical specimens isolated from ovarian endometrioid cysts (OEC) and the endometriosis-associated ovarian tumors obtained after surgical operation from 117 patients. The normal level of serum CA 125 was assumed to be up to $35 \mathrm{IU} / \mathrm{ml}$. Immunohistochemical study of MCK, CK7, CK20, CK 8/18, Calretinin, EMA, Ki67, CEA, Vimentin, Inhibin, WT1, p53, ARID1A (BAF250a), CA 125 antibodies was performed.

Results. The results revealed a direct correlation between the level of serum CA 125 and the WT1 expression in the OEC epithelium (Pearson $r=0.84, \mathrm{p}<0.0001$ ) and between the level of serum CA 125 and the p53 expression (Pearson $r=0.81, \mathrm{p}<0.0001$ ). A striking direct correlation was found when studying the relationship between WT1 and p53 expression in OEC epithelium (Pearson $r=0.79, \mathrm{p}<0.0001$ ).

Conclusion. This research delineated the changes in OEC epithelium, which were similar to the serous epithelial type and associated with an extensive rise in the serum biomarker CA 125 level, which could be indicative of the early neoplastic transformation of OEC.
\end{abstract}

Keywords: CA 125, WT1, p53, ovarian endometrial cyst, ARID1A, malignant transformation

Corresponding author: Olga I. Patsap. E-mail: patsap.o@fccps.ru

For citation: Mikhaleva L.M., Patsap O.I., Bezuglova T.V., Davydov A.I., Aliev G.M. Novel clinical and morphological predictors of malignancy in patients with ovarian endometrioid cysts. Clin. exp. morphology. 2021;10(1):21-32. DOI: 10.31088/CEM2021.10.1.21-32.

Funding. The study was carried out without any sponsorship.

Conflict of interest. The authors declare no conflict of interest.

Received 11.01.2021. Received in revised form 02.02.2021. Accepted 11.02.2021.

УДК: 61:616-091.816

\section{Новые клинико-морфологические предикторы неопластической трансформации у пациенток с эндометриоидными кистами яичников}

\author{
Л.М. Михалева 1 О.И. Пацап 2 Т.В. Безуглова ${ }^{1}$, А.И. Давыдов ${ }^{3}$, Г.М. Алиев $^{1,3,4}$ \\ ${ }^{1}$ ФГБНУ Научно-исследовательский институт морфологии человека, Москва, Россия \\ ${ }^{2}$ ФГБУ Федеральный центр мозга и нейротехнологий ФМБА России, Москва, Россия \\ ${ }^{3}$ Первый Московский государственный медицинский университет имени И.М. Сеченова (Сеченовский университет), \\ Институт клинической медицины имени Н.В. Склифосовского, Москва, Россия \\ ${ }^{4}$ Международный научно-исследовательский институт GALLY, Сан-Антонио, Техас, США
}

Введение. Проблема эндометриоза является неиссякаемым источником для научных исследований, при этом механизмы злокачественной трансформации эндометриоза яичников все еще остаются недостаточно изученными.

Материаль и методы. Исследование проведено на операционном материале эндометриоидных кист яичников (ЭКЯ) и опухолей яичников, полученных после хирургических операций у 117 пациенток. Нормальным уровнем сывороточного онкомаркера СА 125 были приняты значения до 35 ME/мл включительно. Иммуногистохимическое исследование проводилось с использованием маркеров МСК, СK7, CK20, CK 8/18, Calretinin, EMA, Ki67, CEA, Vimentin, Inhibin, WT1, p53, ARID1A (BAF250a), CA 125. Результаты. Выявлена прямая корреляция между уровнем сывороточного СА 125 и экспрессией WT1 в эпителии ЭКЯ (коэффициент Пирсона, $\mathrm{r}=0,84, \mathrm{p}<0,0001$ ) и между уровнем сывороточного CA 125 
и экспрессией p53 в эпителии ЭКЯ (r=0,81, p<0,0001). Сильная прямая корреляция обнаружена при изучении взаимосвязи между экспрессией WT1 и p53 в эпителии ЭКЯ (r=0,79, p<0,0001).

Заключение. По результатам данного исследования выявлены изменения в эпителии ЭКЯ с иммунофенотипом, подобным серозному эпителию, и эти изменения связаны со значительным повышением уровня сывороточного биомаркера СА 125 , что может указывать на раннюю неопластическую трансформацию ЭКЯ.

Ключевые слова: CA 125, WT1, p53, эндометриоидная киста яичника, ARID1A, злокачественная трансформация

Для корреспонденции: Ольга Игоревна Пацап. E-mail: patsap.o@fccps.ru

Для цитирования: Михалева Л.М., Пацап О.И., Безуглова Т.В., Давыдов А.И., Алиев Г.М. Новые клинико-морфологические предикторы неопластической трансформации у пациенток с эндометриоидными кистами яичников. Клин. эксп. морфология. 2021;10(1):21-32 (англ.). DOI: 10.31088/ CEM2021.10.1.21-32.

Финансирование. Исследование не имело спонсорской поддержки.

Конфликт интересов. Авторы заявляют об отсутствии конфликта интересов.

Статья поступила 11.01.2021. Получена после рецензирования 02.02.2021. Принята в печать 11.02 .2021$.

\section{Introduction}

Endometriosis takes the third place in all gynecological diseases after inflammation and leiomyoma. The incidence of endometriosis in fertile women ranges up to $15 \%$ and is one of the most common causes of infertility and chronic pelvic pain syndrome [1-4].

Endometriosis is characterized by ectopic tissue morphologically similar to the endometrium, with glands and stroma. To date, many theories have been proposed, which highlight the etiology, pathogenesis, and natural history of the endometriosis and endometriosis-associated tumors with genetic alterations, changes in the microenvironment, stress factors, etc., but none of them can explain the entire variety of its forms and ability to neoplastic transformation $[1,2,5-7]$.

The history of malignant transformation of endometriosis started in 1925 when John Sampson first described endometriosis-associated malignancy criteria [8]. Malignant transformation of endometriosis is a rare phenomenon that occurs in about $0.7-2.5 \%$ of cases and, when it occurs, it usually involves the ovary $[1,9,10]$. Endometriotic foci also were identified near ovarian epithelial carcinomas and within these carcinomas. So, they were named endometriosis-associated tumors and included predominantly endometrioid, clear-cell carcinomas, and a minor group of seromucinous tumors $[11,12]$. The risk of endometrioid and clear-cell ovarian tumors is 2-3 times higher in women with endometriosis $[10,13]$. Further investigation led to discovering so-called "atypical" endometriosis. It consumes gradual changing of normal endometrioid cyst epithelium into atypical endometriosis with loss of nuclear polarity, hyperchromic nuclei, syncytial papillary changes, large hobnail cells, and then into invasive carcinoma [10]. Endometriosis was significantly associated with borderline ovarian tumors and endometriosis-associated ovarian carcinomas [14]. Atypical endometriosis and endometriosisassociated ovarian tumors have similar molecular changes, such as PTEN, ARIDIA, and $H N F-1 b$ mutations. Moreover, $A R I D 1 A$ mutations were observed in clear-cell tumors and atypical endometriosis but not in distant endometrioid foci $[10,15]$.

The mechanisms of malignant transformation of endometriosis such as genetic, epigenetic factors, microenvironment have been reported earlier [1-15]. The following neoplastic transformation pathways make a significant contribution to the development of "atypical" endometriosis and endometriosis-associated tumors. These include $K R A S / B R A F$ mutations, TP53 mutations, mTOR pathway, ARIDIA mutation, iron metabolism, redox molecules in endometriotic cyst fluid, etc. Previous investigation has revealed a number of pathophysiological changes in endometriosis-associated carcinomas, such as deregulated oxidoreductase activity, metabolism, hormone activity, inflammatory response, innate immune response, and cell-tocell signaling [16]. DNA methylation and demethylation, histone modifications, and miRNA aberrant expressions play a significant role in endometrioid ovarian cyst (OEC) malignant transformation [17]. PI3K-AKT-mTOR, chromatin remodeling (ARIDIA), Notch signaling, and Wnt/ $\beta$ catenin pathway may contribute to OEC malignant transformation [1, 18-20].

Apart from the OEC malignant transformation, such cases have been reported from extraovarian endometriosis, including vaginal, ureteral, or cesarian scar. Most of the extraovarian malignancies are clear-cell or endometrioid carcinomas [21-26]. However, there are rare cases where rhabdomyosarcoma arises from OEC [27].

As previously mentioned, endometriosis-associated tumors could arise from endometrioid cysts [28]. There are reports available that cystic fluid contains several active biomolecules, such as iron, reactive oxygen species, interleukins. Iron-induced oxidative stress and DNA mutations are the basis of iron carcinogenesis, which are followed by the subsequent synthesis of the antioxidants with the decrease in cellular oxidative stress capacity, promotion of apoptosis resistance, and leading to tumor initiation and progression [29, 30]. So, with the help of metallobiology technology, these molecules can be used as non-invasive 
biomarkers for detecting the endometriosis malignant transformation $[31,32]$.

World Health Organization approved the classification of ovarian tumors in 2014 that include high-grade and lowgrade serous carcinomas (HGSC and LGSC, respectively) that differ from each other in genetic disorders, clinical course, and origin [33]. The source of HGSC is the fallopian tube epithelium implanted on the ovarian surface. It is associated with the fallopian tube's serous intraepithelial carcinoma (STIC) and TP53 mutations [11]. LGSC is characterized by $K R A S$ and $B R A F$ mutations and develop sequentially from serous borderline tumors [11].

Glycosylation disorders are known as cancer markers. They lead to tumor-associated glycans and glycoproteins production. The glycosylation marker CA 125 is used for detecting and monitoring serous ovarian tumors. Since glycosylation changes are the early event in the tumor, the identification of tumor-associated markers of glycosylation is an effective strategy in early diagnosis and improving the treatment [34].

The level of serum CA 125 detected in $1 \%$ of healthy female donors can be $35 \mathrm{IU} / \mathrm{ml}$ and is often regarded as the upper limit of the normal reference in the clinical practice. It should be noted that this level is controversial, for example, in postmenopausal women or in patients after hysterectomy, the level of CA 125 tends to decrease, and the lower level may be more acceptable [35]. Approximately $85 \%$ of patients with ovarian epithelial tumors have a serum CA 125 level higher than $35 \mathrm{IU} / \mathrm{ml}$. Serum CA 125 is less often increased in mucinous, clear-cell, and borderline tumors than in serous carcinomas. An increase in serum CA 125 level may also be associated with other malignancies (pancreas, breast, colon, lung tumors) and benign or physiological conditions, including pregnancy, endometriosis, and menstruation [35].

Regarding CA 125 as a marker of endometriosis, many authors are inclined to believe that the level of CA $125 \geq 30 \mathrm{IU} / \mathrm{ml}$ is an indicator of endometriosis with high accuracy only in women with symptoms of pain and infertility. CA 125 should be considered a discriminatory test for suspected endometriosis, and the level of CA $125<30 \mathrm{IU} / \mathrm{ml}$, however, cannot be a criterion for reliable detection of endometriosis [36-39].

The present work suggested that an increased level of serum CA 125 in patients with OEC indicates a change in the morphology and physiology of endometrioid epithelium, reflecting the beginning of the neoplastic transformation of OEC.

The efficient understanding of biological and functional mechanisms depicting OEC complex pathogenesis is considered a significant aspect for developing novel diagnostic and therapeutic strategies. Furthermore, the neoplastic transformation of ovarian endometriosis remains to be understood fully despite decades of research. The present study delineated an extensive rise in the serum levels of CA 125 in OEC conditions, which indicates a change in the morphology and physiology of endometri- oid epithelium conducive to the possible beginning stage of neoplasm.

\section{Patients and methods}

The present study was conducted on the surgical specimen samples obtained from 117 patients. 104 patients were after cystectomy with endometrioid cysts and 13 with ovarian tumors, including endometriosis-associated ones. The age group was chosen from 20 to 83 years (average $36.58 \pm 0.95$ years) during the period of 2016 to 2019 admitted to the Hospital of S.S. Udina City of Moscow Hospital and the Moscow Clinical Hospital \#31. All patients agreed and provided their individual informed consent to analyze their surgical specimen samples with complete Institutional ethical guidelines. Normal range of serum CA 125 was admitted under $35 \mathrm{IU} / \mathrm{ml}$. We divided patients into five groups based on obtained data:

- group 1 includes OEC with normal levels of serum CA 125 cancer biomarker in 69 patients,

- group 2 includes an increased level of serum CA 125 (36-60 IU/ml) in 17 patients,

- group 3 includes an increased level of serum CA 125 (61-90 IU/ml) in 10 patients,

- group 4 includes an increased level of serum CA 125 (91-301 IU/ml) in 8 patients,

- and group 5 includes ovarian carcinomas, i.e., endometrioid (endometriosis-associated ones), serous low- and high-grade with solid, pseudo-endometrioid, transitional cell-like pattern (SET-type) in 13 patients. The serum CA 125 analysis was performed at various laboratories in Moscow using immunochemiluminescent analyzers Architect 1000i (USA) and Immulite 1000 (Japan).

\section{Reagents}

To compare expression in OEC with ovarian tumors, we used a diagnostic panel of mouse monoclonal antibodies against MCK, CK7, CK20, CK 8/18, Calretinin, EMA, Ki67, CEA, Vimentin, Inhibin, WT1, CA 125, ARID1A (BAF250a) (Santa Cruz, USA).

\section{Immunohistochemistry}

OEC and endometriosis-associated tumors surgical specimens were collected into buffered neutral $10 \%$ formalin and subjected to fixation. Paraffin-embedded tissue blocks were prepared through routine histological processing. Immunohistochemical analysis was executed with the aid of the avidin-biotin complex technique. Histological sections were made using Sakura rotary microtomes, stained with hematoxylin and eosin. Immunohistochemistry study of MCK, CK7, CK20, CK 8/18, Calretinin, EMA, Ki67, CEA, Vimentin, Inhibin, WT1, CA 125, ARID1A (BAF250a) antibodies was performed using "Leica BondmaX" immunostainers (Germany).

Interpretation of the immunohistochemical results was carried out considering the localization of positive cells by counting both the number of colored epithelial cells 
per 100 cells in 10 high power fields $(\times 400 / \mathrm{HPF})$ and the intensity of staining. The obtained quantitative results were expressed as a percentage, where 0 - lack of expression, 1 - up to $50 \%$ of colored cells - focal expression, 2 - more than $50 \%$ of colored cells - intense expression of the marker.

The intensity of cytoplasmic expression of the marker was evaluated in points, where 0 - lack of expression, 1 - weak (pale) cell staining, 2 - moderate cell staining, 3 - intense (bright) cell staining.

Ki67 expression was evaluated as follows: 1) $0-20 \%-$ low proliferative activity, 2) 21-50\% - moderate proliferative activity, $51-100 \%$ - high proliferative activity.

The expression of $\mathrm{p} 53$ in a weakly positive reaction was considered corresponding to the wild-type of TP53 gene (weakly positive staining), with total negative or staining of more than $80 \%$ of the nuclei referred to mutant-type of TP53 gene.

\section{Statistics}

Statistical analysis of results was performed using descriptive statistics and a paired t-test, and a correlation between the expression of immunohistochemical markers in OEC epithelial and stromal cells and the level of serum CA 125 . The reliability of the differences in the mean values was calculated using the analysis of variance. The correlation analysis results estimated the relationship between the studied parameters with the Pearson correlation coefficient calculation $(r)$. Also, the nonparametric Mann-Whitney criteria and the Spearman rank correlation coefficient were used in the calculation in cases where parametric statistics methods were incorrect. The data was presented as $\mathrm{M} \pm \mathrm{m}$, where $\mathrm{M}$ is the arithmetic mean and $\mathrm{m}$ is the mean's statistical error. A P-value of 0.05 was considered the cutoff for statistical significance.

\section{Results}

Most patients with OEC (groups 1-4) (98.1\%) and with endometriosis-associated carcinomas (group 5) (82\%) reported nagging pains in the lower abdomen with varying frequency during the menstrual cycle. The body mass index (BMI) ranged from 16.8 to 43 (average $23.08 \pm 0.48$ ) in OEC (groups 1-4) and from 18 to 28 (average, $23.77 \pm 0,8$ ) in group 5, the age of menarche was from 11 to 18 years (average $13.09 \pm 0.13$ years) in groups $1-4$ and 11 to 16 (average, $12.77 \pm 0,4$ ) in group 5. The diameter of OEC ranged from 15 to $135 \mathrm{~mm}$ (average $61.54 \pm 2.72 \mathrm{~mm}$ ) in groups $1-4$ and from 20 to $240 \mathrm{~mm}$ (average $93.8 \pm 16,7 \mathrm{~mm}$ ). Bilateral OEC were detected in 16 patients $(13.68 \%)$ in groups 1-4. Gynecological diseases combined with OEC (groups 1-4) included cervical ectopy in 43 patients (41.3\%), endometrial hyperplasia in $4(3.8 \%)$, infertility I in $2(1.9 \%)$, leiomyoma in $12(11.5 \%)$, adenomyosis in $2(1.9 \%)$, endometrial polyp in $12(11.5 \%)$, endocervical polyp in $4(3.8 \%)$, chronic salpingoophoritis in $5(4.8 \%)$, and less than in $1 \%$ observed ovarian apoplexy, mature cystic teratoma, paraovarian cyst, cervical leukoplakia, HSIL, and chronic endometritis. Three (3) patients had a history of breast fibroadenoma (2.9\%). Twenty-five (25) (24\%) patients had no combined gynecological pathology, and 20 (19\%) patients had more than two diseases (Fig. 1). Gynecological diseases combined with endometriosis-associated tumors (group 5) included leiomyoma in 1 patient (7.7\%).

\section{Combined gynecological diseases in OEC patients}

Expression of MCK, CK7, CK8/18, and EMA markers in OEC and endometriosis-associated ovarian tumors did not differ in all groups and were expressed in all cases. Expression of CK20, CEA, Calretinin, Inhibin, and Vimentin in OEC epithelium and endometriosis-associated ovarian tumors was negative. The expression of proliferation marker Ki67 in OEC did not exceed 5\% in all cases. In contrast, its expression in ovarian tumors was $10-15 \%$ in endometrioid and low-grade serous carcinomas and $50-71 \%$ in high-grade serous carcinoma (SETtype). Expression of the immunohistochemical marker CA 125 was higher in serous ovarian tumors and in the OEC group with elevated serum CA 125 levels above $60 \mathrm{IU} / \mathrm{ml}$. ARID1A (BAF250a) expression was 70-96\% (average $83.73 \pm 0.67 \%$ ) in all groups of OEC, $10-43 \%$ (average 21.6 $\pm 4.5 \%$ ) in endometrioid ovarian carcinomas and $60-67 \%$ (average $64 \pm 1.4 \%$ ) in serous carcinomas lowand high-grade (Table 1).

Significant changes in nuclear expression were detected when evaluating the immunohistochemical reaction for WT1 and p53 expression. The WT1 gene located on chromosome $11 \mathrm{p} 13$ provides protein synthesis is required for the development of normal kidneys and gonads. WT1 protein is a transcription factor significantly involved in the growth, maturation, cell differentiation, and apoptosis in these tissues. The characteristic feature for serous differentiation of OEC epithelial cells is an intense nuclear expression of WT1 both in individual cells and in a group of epithelial cells.

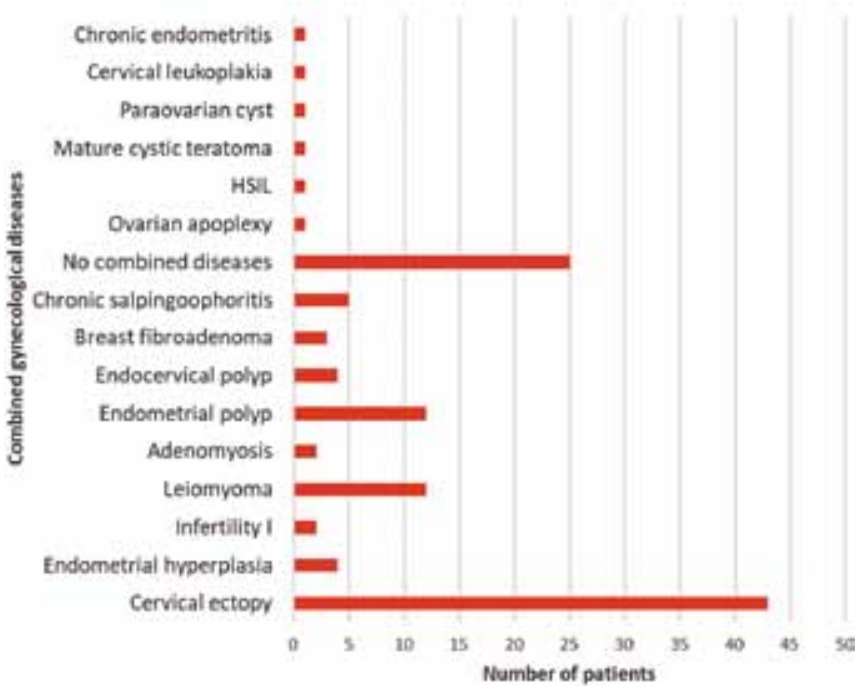

Fig. 1. Combined gynecological diseases in OEC patients

Puc. 1. Комбинированные гинекологические заболевания у пациенток с ЭКЯ 
Expression of IHC markers in all groups |

Экспрессия ИГХ маркеров во всех группах

\begin{tabular}{|c|c|c|c|c|c|c|c|c|c|}
\hline $\begin{array}{l}\text { Group | } \\
\text { Группа }\end{array}$ & MCK & CK7 & CK8/18 & EMA & Ki-67 & WT1 & p53 & CA125 & ARID1A BAF250 \\
\hline $\begin{array}{l}1 \\
(0-35 \mathrm{UE} / \mathrm{ml}) \mid \\
\text { МЕ/мл) }\end{array}$ & $3+$ & $3+$ & $3+$ & $3+$ & $1-2 \%$ & $\begin{array}{c}0-2 \% \\
(0.17 \pm 0.1 \%)\end{array}$ & $\begin{array}{c}\text { Wild-type | Дикий тип, } \\
0-15 \%(2.6 \pm 0.5 \%)\end{array}$ & $1-2+$ & $3+$ \\
\hline $\begin{array}{l}2 \\
36-60 \mathrm{UE} / \mathrm{ml}) \\
\text { МЕ/мл) }\end{array}$ & $3+$ & $3+$ & $3+$ & $3+$ & $1-2 \%$ & $\begin{array}{c}0-6,5 \% \\
(0.76 \pm 0.37 \%)\end{array}$ & $\begin{array}{l}\text { Wild-type | Дикий тип, } \\
1-54 \% \text { (18.74 } \pm 3.52 \%)\end{array}$ & $1-2+$ & $3+$ \\
\hline $\begin{array}{l}3 \\
(61-90 \mathrm{UE} / \mathrm{ml}) \mid \\
\text { МЕ/мЛ) }\end{array}$ & $3+$ & $3+$ & $3+$ & $3+$ & $2-3 \%$ & $\begin{array}{c}0-58 \% \\
(20.7 \pm 6.4 \%)\end{array}$ & 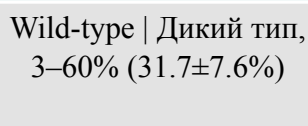 & $2-3+$ & $3+$ \\
\hline $\begin{array}{l}4 \\
(91-301 \mathrm{UE} / \mathrm{ml}) \\
\text { МЕ/мЛ })\end{array}$ & $3+$ & $3+$ & $3+$ & $3+$ & $2-4 \%$ & $\begin{array}{c}62-86 \% \\
(77 \pm 3.01 \%)\end{array}$ & 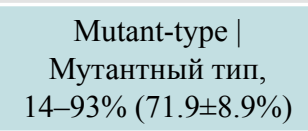 & $2-3+$ & $3+$ \\
\hline $\begin{array}{l}5 \text { endometrioid | } \\
\text { эндометриоидные }\end{array}$ & $3+$ & $3+$ & $3+$ & $3+$ & $10-15 \%$ & $0 \%$ & $\begin{array}{l}\text { Wild-type | } \\
\text { Дикий тип }\end{array}$ & $1-2+$ & $\begin{array}{l}\text { Loss of expression } \\
\text { in } 60 \% \text { of cells | } \\
\text { Потеря экспрессии } \\
\text { в } 60 \% \text { клеток }\end{array}$ \\
\hline $\begin{array}{l}5 \text { serous low-grade } \\
\text { low-grade серозные }\end{array}$ & $3+$ & $3+$ & $3+$ & $3+$ & $10-15 \%$ & $35-50 \%$ & $\begin{array}{l}\text { Wild-type | } \\
\text { Дикий тип }\end{array}$ & $2-3+$ & $3+$ \\
\hline $\begin{array}{l}5 \text { serous high grade } \\
\text { (SET-type) } \\
\text { high-grade cерозные } \\
\text { (SET-типа*) }\end{array}$ & $3+$ & $3+$ & $3+$ & $3+$ & $50-71 \%$ & $50-80 \%$ & $\begin{array}{c}\text { Mutant-type| } \\
\text { Мутантный тип }\end{array}$ & $2-3+$ & $3+$ \\
\hline
\end{tabular}

*SET-тип - серозная карцинома high-grade с солидными, эндометриоидными и переходноклеточными участками строения.

The nuclear expression of WT1 in the OEC epithelium was predominantly negative in the patients of 1-2 group with serum CA 125 levels up to $60 \mathrm{IU} / \mathrm{ml}(0-35$; 36-60 IU/ml). However, a few positive nuclear expression cases of WT1 were observed in individual epithelial cells and were up to $6.5 \%$ (average $0.4 \pm 0.1 \%$ ). Positive nuclear expression was observed in stromal cells in all cases in all groups and was $41-78.3 \%$ (average $67.9 \pm 5.6 \%$ ). Patients with elevated levels of serum CA $12561-90 \mathrm{IU} / \mathrm{ml}$ showed a positive nuclear expression up to $58 \%$ (average $20.7 \pm 6.4 \%$ ) of OEC epithelial cells. Patients with elevated levels of serum CA $12591-301 \mathrm{IU} / \mathrm{ml}$ demonstrated the positive nuclear expression in $62-86 \%$ epithelial cells (average, $77.0 \pm 3.01 \%$ ). Positive nuclear expression of WT1 was also observed in stromal cells in all cases in $47-56 \%$ (average, $51.6 \pm 5.2 \%$ ) of cells (Fig. 2, 3).

Correlation between the serum CA 125

and WT1 expression in epithelial and stromal OEC clinicopathology

Relationship between levels of serum CA 125 and WT1, p53, ARID1A (BAF250a) expression in epithelial and stromal OEC clinicopathology

WT1 nuclear expression was observed focally in OEC epithelium along with epithelium with a negative reaction. It was noted that with an increase in serum CA 125 level, there was an increase in the number of such foci. However, even at level $301 \mathrm{IU} / \mathrm{ml}$, foci of epithelium with a negative expression remained in OEC. The expression of WT1 was ambiguous in 13 patients with ovarian carcinomas: group of endometrioid carcinomas ( $n=9)$ : 8 exhibited negative expression, 1-weak focal and uneven (about 1\% of cells); group of serous tumors (low-grade, $\mathrm{n}=3$ ) was $35-50 \%$ and in serous carcinoma high-grade (SET-type), $\mathrm{n}=1$, it was $50-80 \%$.

The expression of protein p53 was predominantly wild-type, while the percentage of nuclear expression in

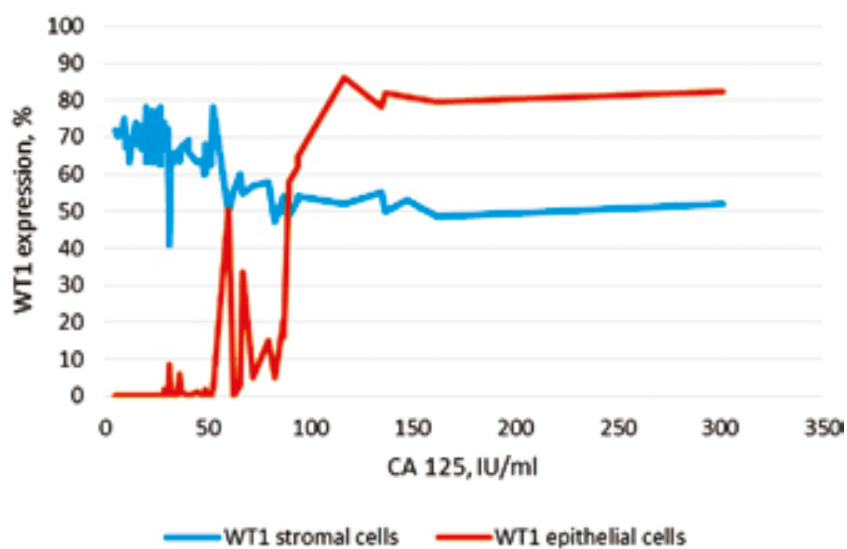

Fig. 2. WT1 expression in OEC epithelial and stromal cells

Puc. 2. Экспрессия WT1 в эпителиальных и стромальных клетках ЭКЯ 
Serum CA 125 level,

IU/ml |

Уровень сывороточного

СА 125, МЕ/мл

Under $60 \mathrm{IU} / \mathrm{ml}$

Менее $60 \mathrm{ME/мл}$

More than $60 \mathrm{IU} / \mathrm{ml}$

in negative WT1

expression areas |

Свыше $60 \mathrm{ME} /$ мл

в областях с негативной

экспрессией WT1

More than $60 \mathrm{IU} / \mathrm{ml}$ in positive WT1 expression areas $\mid$ Свыше $60 \mathrm{ME} / \mathrm{мл}$ в областях

с положительной экспрессией WT1
WT1 expression |

Экспрессия WT1

p53 expression |

Экспрессия р53
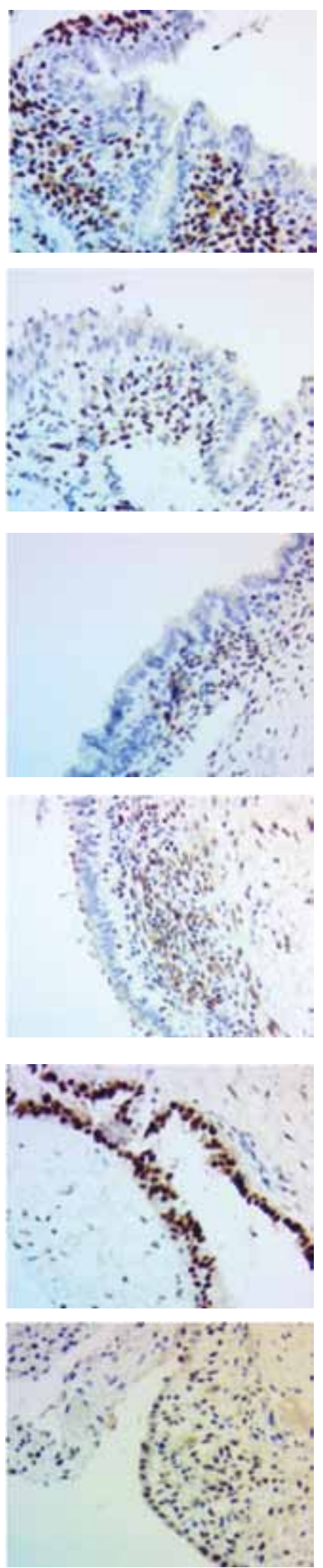
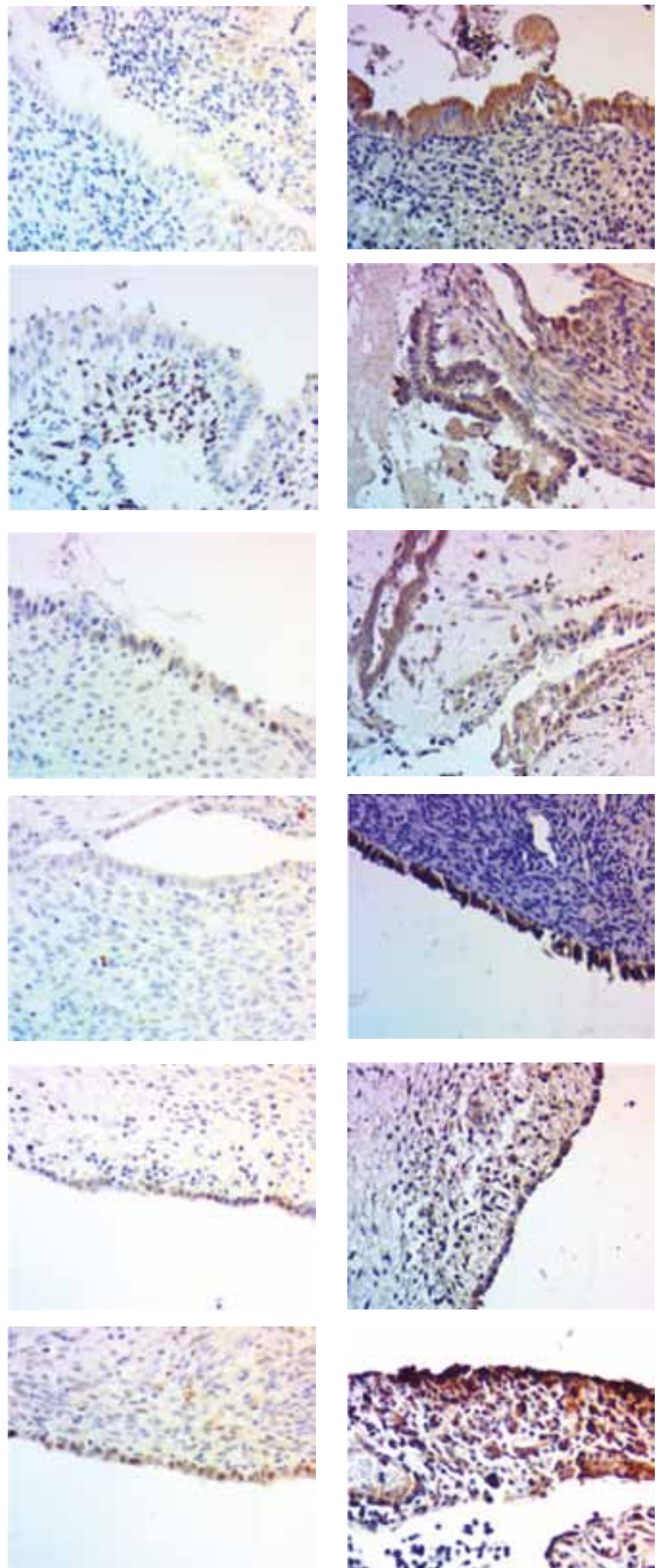

ARID1A (BAF250a)

expression |

Экспрессия $A R I D 1 A$

(BAF250a)
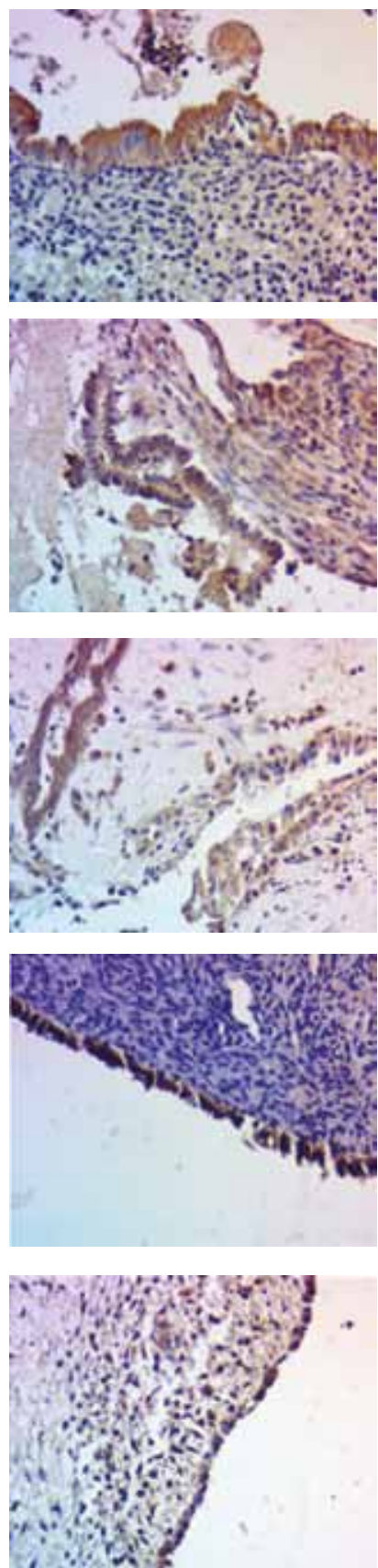

(20)

Fig. 3. WT1, p53, and ARID1A (BAF250a) expression in OEC epithelial and stromal cells

Puc. 3. Экспрессия WT1, p53 и ARID1A (BAF250a) в эпителиальных и стромальных клетках ЭКЯ 


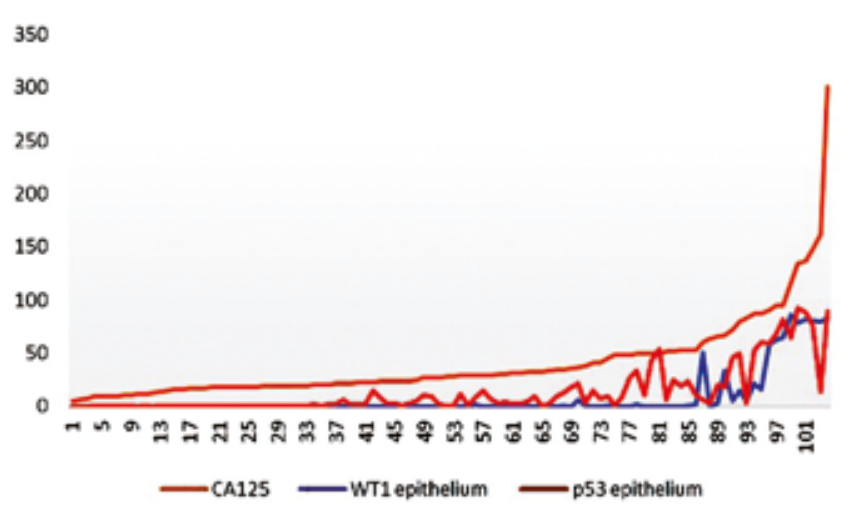

Fig. 4. WT1 and p53 expression in OEC epithelial cells

Puc. 4. Экспрессия WT1 и р53 в эпителиальных клетках ЭКЯ

OEC epithelial cells gradually but unevenly increased with increasing level of serum CA 125 and ranged from 0 to $75 \%$ (average $13.77 \pm 2.21 \%$ ) in 99 cases. The expression level of p53 was over $80 \%$ in 4 cases with serum CA 125 levels 94.3-301 IU/ml, which is an indicator of pathological expression of p53 (Fig. 3, 4). P53 expression was predominantly wild-type, and the percentage of expression was $15-82 \%$ (average $33.56 \pm 4.6 \%$ ) in endometrioid and serous low-grade ovarian tumors, and the mutant-type expression was detected in high-grade serous carcinoma (SET-type).

\section{WT1 and p53 expression in OEC epithelial cells}

Statistical analysis of this data was completed. We have identified a strong direct correlation between the serum CA 125 level and the WT1 expression level in the OEC epithelium (Pearson correlation coefficient $(r)=0.84, \mathrm{p}<0.0001$ ) and between the serum CA 125 level and p53 expression
(Pearson, $r=0.81, \mathrm{p}<0.0001$ ). There was a moderate inverse relationship between the serum CA 125 level and the WT1 expression level in the OEC stroma (Pearson, $r=-0.68$, $\mathrm{p}=0.002)$ and between WT1 expression in the epithelium and stroma of OEC (Pearson, $r=-0.69, \mathrm{p}=0,5$ ).

When studying the relationship between the expression of WT1 and p53 in the OEC epithelium, a strong direct correlation was revealed (Pearson, $r=0.79, \mathrm{p}<0.0001$ ), which may be associated with early neoplastic transformation.

BMI and OEC diameter were also evaluated in this study $[40,41]$. Studies of the Pearson correlation coefficient for samples over 60 were conducted, and nonparametric statistics such as the Mann-Whitney coefficient (U) and Spearman correlation coefficient $(\mathrm{P})$ were evaluated. When evaluating the Mann-Whitney coefficient, no differences were found in the samples in groups I-II and V. Significant differences in the samples were found in groups III and IV. At the same time, there was no significant correlation between the size of the OEC, BMI, and the expression of CA125, WT1, and p53 in groups I-II (0-60 IU/ml), the Spearman coefficient ranges $-0.02-0.4$, which indicates a weak direct/inverse correlation. In group III (61-90 IU/ml), a moderate direct relationship was found between the OEC size and the expression of the immunohistochemical markers WT1 and p53 and a moderate inverse relationship between BMI and the level of p53 expression. There was a moderate direct relationship between the OEC size and the level of serum CA 125, as well as the level of p53 expression, and a moderate inverse relationship between BMI and WT1 expression in group IV (91-301 IU/ml). A moderate inverse relationship between BMI and WT1 expression was also found in the group of ovarian tumors. Summary data of parametric and nonparametric correlation in OEC groups are in Table $2 \mathrm{a}, 2 \mathrm{~b}$.

Summary data of correlation in all OEC groups (Pearson, r) |

Сводные корреляционные данные во всех группах ЭКЯ (критерий Пирсона, r)

\begin{tabular}{|c|c|c|c|c|c|}
\hline & $\begin{array}{c}\text { Serum CA 125, } \\
\text { IU/mI | } \\
\text { Уровень СA } 125 \\
\text { в сыворотке } \\
\text { крови, МЕ/мл }\end{array}$ & $\begin{array}{c}\text { Body mass } \\
\text { index, } \mathbf{k g} / \mathrm{m}^{2} \text { | } \\
\text { Индекс } \\
\text { массы тела, } \\
\text { кг } / \mathbf{m}^{2}\end{array}$ & $\begin{array}{c}\text { OEC diameter, } \\
\text { mm | } \\
\text { Диаметр } \\
\text { ЭКЯ, мм }\end{array}$ & $\begin{array}{c}\text { P53 expression in } \\
\text { ерithelium, \% | } \\
\text { Экспрессия P53 } \\
\text { в эпителии, \% }\end{array}$ & $\begin{array}{c}\text { WT1 expression } \\
\text { in epithelium, \% | } \\
\text { Экспрессия WT1 } \\
\text { в эпителии, \% }\end{array}$ \\
\hline $\begin{array}{l}\text { Serum CA } 125, \mathrm{IU} / \mathrm{ml} \mid \\
\text { Уровень CA } 125 \text { в сыворотке } \\
\text { крови, IU/ml }\end{array}$ & - & $-0,14$ & 0,09 & 0,81 & 0,84 \\
\hline 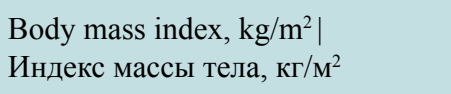 & $-0,14$ & - & $-0,06$ & $-0,14$ & $-0,11$ \\
\hline $\begin{array}{l}\text { OEC diameter, mm | } \\
\text { Диаметр ЭКЯ, мм }\end{array}$ & 0,09 & $-0,06$ & - & 0,14 & 0,11 \\
\hline $\begin{array}{l}\text { P53 expression in epithelium, \% | } \\
\text { Экспрессия Р53 в эпителии, \% }\end{array}$ & 0,81 & $-0,14$ & 0,14 & - & 0,79 \\
\hline $\begin{array}{l}\text { WT1 expression in epithelium, \% | } \\
\text { Экспрессия WT1 в эпителии, \% }\end{array}$ & 0,84 & $-0,11$ & 0,11 & 0,79 & - \\
\hline
\end{tabular}


Table $2 b \mid$ Таблица $2 b$

Correlation between BMI/OEC diameter and WT1, p53 expression depending on serum CA 125 level (Spearman, rs) | Корреляция между индексом массы тела (ИМТ)/ и диаметром ЭКЯ и экспрессией маркеров WT1, p53 в зависимости от сывороточного уровня CA 125 (IU/ml | ME/мл) (критерий Спирмана, rs)

\begin{tabular}{|c|c|c|c|c|c|c|}
\hline \multirow[t]{2}{*}{$\begin{array}{l}\text { Groups | } \\
\text { Группы }\end{array}$} & \multicolumn{3}{|c|}{$\begin{array}{l}\text { OEC diameter| } \\
\text { Диаметр ЭКЯ }\end{array}$} & \multicolumn{3}{|c|}{ ВМІ | ИМТ } \\
\hline & WT1 & p53 & CA 125 & WT1 & p53 & CA 125 \\
\hline I (CA $125=0-35$ IU/ml | МЕ/мЛ) & $-0,2$ & 0,2 & 0,09 & $-0,1$ & $-0,16$ & $-0,14$ \\
\hline II (CA 125 = 36-60 IU/ml | ME/мл) & 0,4 & 0,01 & $-0,02$ & $-0,2$ & $-0,22$ & $-0,2$ \\
\hline III (CA 125 = 61-91 IU/ml | МЕ/мл) & 0,5 & 0,6 & 0,3 & $-0,35$ & $-0,6$ & $-0,3$ \\
\hline IV (CA $125=90-301 \mathrm{IU} / \mathrm{ml} \mid$ МЕ/мл) & 0,24 & 0,57 & 0,65 & $-0,57$ & $-0,19$ & $-0,4$ \\
\hline V (ovarian tumors | опухоли яичника) & $-0,1$ & $-0,2$ & $-0,3$ & $-0,6$ & $-0,1$ & $-0,3$ \\
\hline
\end{tabular}

\section{Discussion}

CA125 is a significant marker, and it is mostly used to identify disease conditions, including OEC. Predominantly, the CA125 levels are reported to be enhanced in $80-85 \%$ in females with advanced stages of ovarian cancer and endometriosis. Hence, it is referred to as a suitable cancer marker to monitor ovarian tumor progression, differentiation, and regression to foster early diagnosis [38]. A plethora of research studies established a positive link between endometriosis and certain groups of ovarian tumors, such as endometrioid, clear-cell, and serous lowgrade, based on data from more than 21,000 patients [42]. Yiying Wang et al. reported that the immunohistochemical expression of markers OVGP1, WT1, and FMO in LGSCs and concluded these carcinomas develop from tubal-type epithelium of ovarian cystic inclusions [43, 44]. Abnormal expression of the WT1 protein is well known as a serous differentiation marker since it has a positive expression in serous ovarian tumors $[45,46]$. A method exists for differential diagnosis of ovarian HGSC and LGSC based on the p53/P16 ratio. However, the authors of this study noted that routine morphological diagnosis is better associated with the patient survival outcome [47]. The same authors provide data that WT1 expression was observed in $71.4 \%$ of LGSC and $57.1 \%$ of HGSC, p53 expression was completely negative in $81 \%$ of LGSC and $30.6 \%$ of HGSC, focal in $9.5 \%$ of LGSC and $1.2 \%$ of HGSC, diffuse in $9.5 \%$ of LGSC and $68.2 \%$ of HGSC [47]. Other investigators did not find p53 expression in solitary endometriosis, and endometriosis coexisted with endometriosis-associated tumors [48]. However, they explored a small sample of 29 cases without any significant correlations with serum biomarkers. Ma X et al. suggested that PTEN mutation is an early indicator and p53 mutation is a later indicator in malignant transformation of endometriosis [49]. We also found p53 expression over $75 \%$ in 5 cases with serum CA 125 levels 94.3-301 IU/ml, which may reflect the serous epithelial transformation that had existed for a long time and possibly is at the beginning of neoplastic changes.
According to our data, there was focal serous differentiation of OEC epithelium with expression of serous markers such as WT1 and p53 with an increase in the CA 125 level more than $60 \mathrm{IU} / \mathrm{ml}$. We found that the IHCprofile for normal endometrioid epithelium was WT1-/ p53wt/ARID1A+ and was characteristic for groups 1-2 $(0-35 ; 36-60 \mathrm{IU} / \mathrm{ml})$. When comparing the IHC-profile of OEC group $3(61-90 \mathrm{IU} / \mathrm{ml})$ with group 5 (endometriosis-associated tumors), we stated their equality, i.e., WT1+/p53wt/ARID1A+. Moreover, when we compare the IHC-profile of group $4(91-301 \mathrm{IU} / \mathrm{ml})$ to group 5, these were similar: WT1+/p53mt/ARID1A + . These findings suggest the neoplastic transformation to serous ovarian borderline tumors and LGSC. We found OECs share similar immunohistochemical profiles with serous ovarian carcinomas, but not with the endometrioid ones because the expression of WT1 and p53 were not observed, and there was no lack of ARID1A expression. The expressions of WT1 and p53 levels were focal across the endometrioid carcinomas. Besides, ARID1A (BAF250a) expression in OEC was close to that in serous low-grade carcinomas and differed from endometrioid ones. Moreover, there is a clinical case that demonstrated OEC malignant transformation to well-differentiated endometrioid carcinoma with normal serum CA 125 [50], which supports our supposition that OEC may transform to serous ovarian tumor, and this process is accompanied by an increase in serum CA 125 level.

Bulun et al. established that endometriotic stromal cells are mutation-free. We likewise found that the stromal cells did not display any changes in immunohistochemical marker expression. These authors have depicted that the stroma cells contain widespread epigenetic defects, which could alter gene expression and induce a progesteroneresistance and inflammation. Subsequent estrogenic action in the stroma results in paracrine signaling to neighboring epithelial cells, which may enhance proliferation, causing mutation accumulation and malignant transformation in OEC epithelial cells that may lead to epithelial ovarian cancer [51]. 


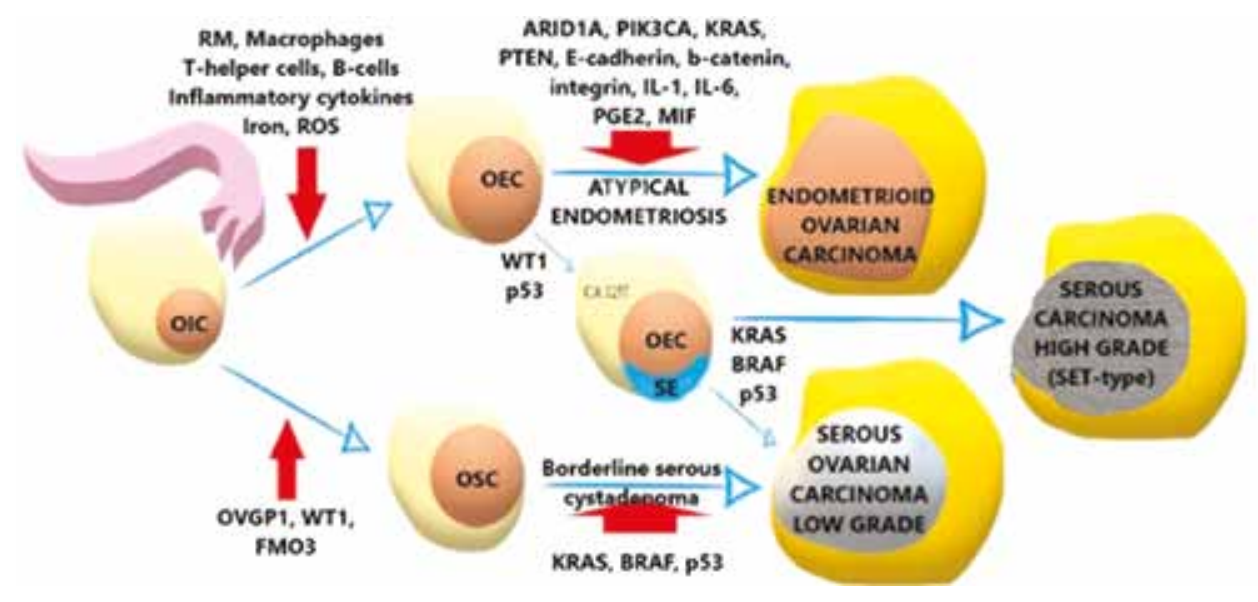

Fig. 5. Possible mechanisms of neoplastic transformations of OEC. OIC - ovarian inclusion cyst; OEC - ovarian endometrioid cyst; OSC - ovarian serous cystadenoma; RM - retrograde menstruation; ROS - reactive oxygen species; SE - serous epithelium; OVGP1 - oviduct-specific glycoprotein 1; WT1 - Wilm's tumor protein; FMO3 - flavin-containing monooxygenase 3; ARIDIA - AT-rich interactive domain-containing protein 1A; PIK3CA - phosphatidylinositol-3-kinase, catalytic subunit; KRAS - RAS/MAPK pathway protein; BRAF - v-RAF murine sarcoma viral oncogene homolog b; PTEN - homolog of phosphatase and tensin; IL-1 - interleukin 1; IL-6 - interleukin 6; PGE2 - prostaglandin E2; MIF - macrophage migration inhibitory factor; p53 - p53 protein; CA 125 - cancer antigen 125

Puc. 5. Предположительные механизмы неопластической трансформации ЭКЯ. ОІС - инклюзионная киста яичника; OEC - эндометриоидная киста яичника; OSC - серозная цистаденома яичника; RM - ретроградная менструация; $\mathrm{ROS}$ - активные формы кислорода; SE - серозный эпителий; OVGP1 - яйцеводспецифичный гликопротеин 1; WT1 - белок опухоли Вильмса; FMO3 - флавинсодержащая монооксигеназа 3; ARIDIA - AT-насыщенный интерактивный домен, содержащий белок 1А; PIK3CA - фосфатидилинозитол-3-киназа, каталитическая субъединица альфа; KRAS - белок пути RAS/MAPK; BRAF - гомолог b вирусного онкогена мышиной саркомы v-RAF; $P T E N$ - гомолог фосфатазы и тензина; ИЛ-1 - интерлейкин 1; ИЛ-6 - интерлейкин 6; PGE2 - простагландин Е2; MIF - фактор ингибирования миграции макрофагов; р53 - белок р53; CA 125 - опухолевый антиген 125

In this regard, a scheme for the possible development of ovarian carcinomas from OEC was proposed (Fig. 5). Our results reported that OEC could be precursors to both endometrioid carcinomas via the ARID1A, PI3K/AKT, MAPK/ERK pathways, and serous carcinomas via the TP53, RAS/MAPK pathways.

\section{Conclusion}

Evaluation of immunohistochemical expression of WT1 and $\mathrm{p} 53$ markers in the OEC with increased serum CA 125 level is beneficial to oncologists to choose a suitable therapeutic modality with adequate follow-up to the patients. Our present study results replicate previously published reports. Furthermore, the results indicate an early change in the epithelium that may give rise to neoplastic transformation is feasible. However, the mechanism of neoplastic transformation remains only partially understood and requires extensive research.

\section{Human and animal rights}

All the study procedures were approved by the US NIH Ethical Standards. Animals were not used for this study. Consent was obtained from all the humans in this study. The procedures were in accordance with the ethical standards of the committee responsible for human experimentation (institutional and national) and with the NIH ethical guidelines.

\section{Compliance with ethics guidelines}

This article is based on research that was ethically approved by the Local Ethical Committee of the City Clinical Hospital No. 31, Moscow, and Institute of Human Morphology, Moscow, Russia (Approval Protocol No. 3, 12.06.2019).

\section{Author contributions}

Compiling and combining edits for additional drafts; assembly of data, results, and references; writing - original draft - L.M. Mikhaleva, O.I. Patsap.

Assembly of cases; slide scanning; survey creation, blinded review of slides - T.V. Bezuglova, A.I. Davydov, G.M. Aliev.

Study conceptualization; digital slide review, writing - review, and editing - L.M. Mikhaleva, O.I. Patsap, G.M. Aliev.

Each author has participated sufficiently in work to take public responsibility for the content as per ICMJE guidelines; authorship credit should be based on substantial contributions to conception and design, acquisition of data, or analysis and interpretation of data; drafting the article or revising it critically for important intellectual content; final approval of the version to be published; and agreement to be accountable for all aspects of the work.

\section{Вклад авторов}

Сбор данных, анализ результатов; написание оригинального текста статьи, составление списка литературы, внесение правок Л.М. Михалева, О.И. Пацап.

Сбор клинических случаев; сканирование микропрепаратов; создание отчета об обследовании, анализ микропрепаратов слепым методом - Т.В. Безуглова, А.И. Давыдов, Г.М. Алиев. 
Концепция исследования; анализ оцифрованных микропрепаратов, написание обзора и редактирование текста Л.М. Михалева, О.И. Пацап, Г.М. Алиев.

Каждый автор в достаточной степени участвовал в работе, чтобы вынести ее на всеобщее обозрение, взять ответственность за ее содержание в соответствии с руководящими принципами ICMJE; признание авторства основывается на существенном вкладе в разработку концепции и дизайна; сборе, анализе и интерпретации данных; написании статьи или ее критическом рецензировании и внесении правок, имеющих решающее значение для интеллектуального содержания; окончательном утверждении версии для публикации и согласии нести ответственность по всем аспектам работы.

\section{References/Литература}

1. Mikhaleva LM, Davydov AI, Patsap OI, Mikhaylenko EV, Nikolenko VN, Neganova ME et al. Malignant transformation and associated biomarkers of ovarian endometriosis: Anarrative review. AdvTher. 2020;37(6):2580-2603 (2020). DOI: 10.1007/ s12325-020-01363-5.

2. Davydov AI, Mikhaleva LM, Patsap OI. On markers of early detection of endometriosis-associated ovarian tumours. Gynecology, Obstetrics and Perinatology. 2019;18(4):133-137 (In Russ.). DOI: 10.20953/1726-1678-2019-4-133-137.

Давыдов А.И., Михалева Л.М., Пачап О.И. К вопросу о маркерах ранней детекции эндометриоз-ассоциированных опухолей яичника. Вопросы гинекологии, акушерства и перинатологии. 2019;18(4):133-137. DOI: 10.20953/1726-1678-2019-4-133-137.

3. Gajbhiye R, Bendigeri T, Ghuge A, Bhusane K, Begum S, Warty N et al. Panel of autoimmune markers for non-invasive diagnosis of minimal-mild endometriosis. Reprod Sci. 2017;24(3):413-20. DOI: $10.1177 / 1933719116657190$.

4. Socolov R, Socolov D, Sindilar A, Pavaleanu I. An update on the biological markers of endometriosis. Minerva Ginecol. 2017;69(5):462-7. DOI: 0.23736/S0026-4784.17.04046-1.

5. Davydov AI, Mikhaleva LM, Tairova MB, Patsap OI. Ovarian endometriosis: a form of genital endometriosis or a specific nosological unit. Gynecology, Obstetrics and Perinatology. 2019; 18(5):5-12 (In Russ.). DOI: 10.20953/1726-1678-2019-5-5-12. Давыдов А.И., Михалева Л.М., Таирова М.Б., Пацап О.И. Эндометриоз яичников: форма генитального эндометриоза или отдельная нозологическая единица? Вопросы гинекологии, акушерства и перинатологии. 2019;18(5):5-12. DOI: 10.20953/1726-1678-2019-5-5-12.

6. Lin Q, Ding SJ, Zhu TH, Li TT, Huang XF, Zhang XM. Role and clinical significance of coagulation and inflammatory factors in moderate and severe ovarian endometriosis. Zhonghua Fu Chan Ke Za Zhi. 2018;53(3):167-71. DOI: 10.3760/cma.j.issn.0529567X.2018.03.005.

7. Sapalidis K, Machairiotis N, Zarogoulidis P, Vasilakaki S, Sardeli $C$, Koimtzis $G$ et al. Genes' interactions: Amajor contributor to the malignant transformation of endometriosis. Int J Mol Sci. 2019;20(8):1842. DOI: 10.3390/ijms20081842.

8. Taniguchi $F$. New knowledge and insights about the malignant transformation of endometriosis. J Obstet Gynaecol Res. 2017;43(7):1093-100. DOI: 10.1111/jog.13372.

9. Kim HS, Kim TH, Chung HH, Song YS. Risk and prognosis of ovarian cancer in women with endometriosis: a meta-analysis. Br J Cancer. 2014;110(7):1878-90. DOI: 10.1038/bjc.2014.29.
10. Gadducci A, Lanfredini N, Tana R. Novel insights on the malignant transformation of endometriosis into ovarian carcinoma. Gynecol Endocrinol. 2014;30(9):612-7. DOI:10.3109/095135 90.2014.926325.

11. Kurman RJ, Shih IeM. The dualistic model of ovarian carcinogenesis: Revisited, revised, and expanded. Am J Pathol. 2016;186(4):733-47. DOI: 10.1016/j.ajpath.2015.11.011.

12. Anglesio MS, Yong PJ. Endometriosis-associated ovarian cancers. Clin Obstet Gynecol. 2017;60(4):711-27. DOI: 10.1097/ GRF.0000000000000320.

13. Kuo HH, Huang CY, Ueng SH, Huang KG, Lee CL, Yen CF. Unexpected epithelial ovarian cancers arising from presumed endometrioma: A 10-year retrospective analysis. Taiwan J Obstet Gynecol. 2017;56(1):55-61. DOI: 10.1016/j.tjog. 2015.09.009.

14. Oral E, Aydin O, Kumbak BA, Ilvan S, Yilmaz H, Tustas E et al. Concomitant endometriosis in malignant and borderline ovarian tumours. J Obstet Gynaecol. 2018;38(8):1104-9. DOI: 10.1080/01443615.2018.1441815.

15. Xiao W, Awadallah A, Xin W. Loss of ARID1A/BAF250a expression in ovarian endometriosis and clear cell carcinoma. Int J Clin Exp Pathol. 2012;5(7):642-50. PMID: 22977660.

16. Chang CM, Yang YP, Chuang JH, Chuang CM, Lin TW, Wang $P H$ et al. Discovering the deregulated molecular functions involved in malignant transformation of endometriosis to endometriosis-associated ovarian carcinoma using a data-driven, function-based analysis. Int J Mol Sci. 2017;18(11):2345. DOI: 10.3390/ijms 18112345 .

17. He J, Chang W, Feng C, Cui M, Xu T. Endometriosis malignant transformation: epigenetics as a probable mechanism in ovarian tumorigenesis. Int J Genomics. 2018; 1465348. DOI: $10.1155 / 2018 / 1465348$.

18. Er TK, Su YF, Wu CC, Chen CC, Wang J, Hsieh TH, et al. Targeted next-generation sequencing for molecular diagnosis of endometriosis-associated ovarian cancer. J Mol Med (Berl). 2016;94(7):835-47. DOI:10.1007/s00109-016-1395-2.

19. Takeda T, Banno K, Okawa R, Yanokura M, Iijima M, IrieKunitomi $H$ et al. ARID1A gene mutation in ovarian and endometrial cancers (Review). Oncol Rep. 2016;35(2):607-13. DOI: 10.3892/or.2015.4421.

20. Lakshminarasimhan R, Andreu-Vieyra C, Lawrenson K, Duymich CE, Gayther SA, Liang $G$ et al. Down-regulation of ARID1A is sufficient to initiate neoplastic transformation along with epigenetic reprogramming in non-tumorigenic endometriotic cells. Cancer Lett. 2017;401:11-19. DOI: 10.1016/j.canlet.2017.04.040.

21. Cozzolino M, Nasioudis D, Sisti G, Coccia ME. Malignant transformation of vaginal endometriosis - A review of literature. Gynecol Obstet Invest. 2017;82(2):105-12. DOI: 10.1159/000449198.

22. Barra F, Scala C, Biscaldi E, Vellone VG, Ceccaroni M, Terrone $C$ et al. Ureteral endometriosis: a systematic review of epidemiology, pathogenesis, diagnosis, treatment, risk of malignant transformation and fertility. Hum Reprod Update. 2018;24(6):710-30. DOI: 10.1093/humupd/dmy027.

23. Mihailovici A, Rottenstreich M, Kovel S, Wassermann I, Smorgick N, Vaknin Z. Endometriosis-associated malignant transformation in abdominal surgical scar: A PRISMA-compliant 
systematic review. Medicine (Baltimore). 2017;96(49):e9136. DOI: 10.1097/MD.0000000000009136.

24. Takeuchi M, Matsuzaki K, Bando Y, Nishimura M, Yoneda A, Harada $M$. A case of polypoid endometriosis with malignant transformation. AbdomRadiol (NY). 2016;41(9):1699-702. DOI: 10.1007/s00261-016-0696-9.

25. Gentile JKA, Migliore R, Kistenmacker FJN, Oliveira MM, Garcia RB, Bin FC et al. Malignant transformation of abdominal wall endometriosis to clear cell carcinoma: case report. Sao Paulo Med J. 2018;136(6):586-90. DOI: 10.1590/15163180.2017.0103300417.

26. $J i W, W u J$, Cheng $J, D i W$. Serous adenocarcinoma arising from endometriosis in cesarean section abdominal wall scar: a case report and literature review. Int J Clin Exp Pathol. 2017;10(7):7534-41. PMID: 31966597.

27. Nezhat C, Vu M, Vang N, Ganjoo K, Karam A, Folkins A et al. Endometriosis malignant transformation review: Rhabdomyosarcoma arising from an endometrioma. JSLS. 2019;23(4):e2019.00038. DOI: $10.4293 /$ JSLS.2019.00038.

28. Oral E, Sozen I, Uludag S, Demirkiran F, Ilvan S, Oncul Met al. The prevalence of endometrioma and associated malignant transformation in women over 40 years of age. J Gynecol Obstet Hum Reprod. 2020;49(5):101725. DOI: 10.1016/j.jogoh.2020.101725.

29. Kobayashi H, Yamada Y, Kawahara N, Ogawa K, Yoshimoto $C$. Integrating modern approaches to pathogenetic concepts of malignant transformation of endometriosis. Oncol Rep. 2019;41(3):1729-38. DOI: 10.3892/or.2018.6946.

30. Iwabuchi T, Yoshimoto C, Shigetomi H, Kobayashi H. Oxidative stress and antioxidant defense in endometriosis and its malignant transformation. Oxid Med Cell Longev. 2015;2015:848595. DOI: 10.1155/2015/848595.

31. Kobayashi H, Yamada Y, Kawahara N, Ogawa K, Yoshimoto C. Modern approaches to non-invasive diagnosis of malignant transformation of endometriosis. Oncol Lett. 2019;17(1):1196-202. DOI: 10.3892/ol.2018.9721.

32. Iwabuchi T, Yoshimoto C, Shigetomi H, Kobayashi H. Cyst fluid hemoglobin species in endometriosis and its malignant transformation: The role of metallobiology. Oncol Lett. 2016;11(5):3384-8. PMID: 27123121.

33. RJ Kurman, ML Carcangiu, CS Herrington, RH Young (eds.). WHO classification of tumours of female reproductive organs. Lyon: IARC Press, 2014. 307 p.

34. Silsirivanit A. Glycosylation markers in cancer. Adv Clin Chem. 2019;89:189-213. DOI: 10.1016/bs.acc.2018.12.005.

35. Crosby DA, Glover LE, Martyn F, Wingfield M. CA125 measured during menstruation can be misleading. Ir Med J. 2018;111(4):738. PMID: 30488683.

36. Akinwunmi BO, Babic A, Vitonis AF, Cramer DW, Titus L, Tworoger SS et al. Chronic medical conditions and CA125 levels among women without ovarian cancer. Cancer Epidemiol Biomarkers Prev. 2018;27(12):1483-90. DOI: 10.1158/1055-9965. EPI-18-0203.

37. Hirsch M, Duffy J, Davis CJ, Nieves Plana M, Khan KS. International Collaboration to harmonise outcomes and measures for endometriosis. Diagnostic accuracy of cancer antigen 125 for endometriosis: a systematic review and meta-analysis. BJOG. 2016;123(11):1761-8. DOI: 10.1111/1471-0528.1405.
38. Hirsch M, Duffy JMN, Deguara CS, Davis CJ, Khan KS. Diagnostic accuracy of Cancer Antigen 125 (CA125) for endometriosis in symptomatic women: A multi-center study. Eur J Obstet Gynecol Reprod Biol. 2017;210:102-7. DOI: 10.1016/j. ejogrb.2016.12.002.

39. Karimi-Zarchi M, Dehshiri-Zadeh N, Sekhavat L, Nosouhi F. Correlation of CA-125 serum level and clinico-pathological characteristic of patients with endometriosis. Int J Reprod Biomed. 2016;14(11):713-8. PMID: 28008424.

40. Zhou Y, Hиа $K Q$. Ovarian endometriosis: risk factor analysis and prediction of malignant transformation. Przeglad Menopauzalny (Menopause Review). 2018;17(1):43-8. DOI: $10.5114 /$ pm.2018.74902.

41. Zhang Y, Qu P. Factors associated with ovarian endometriosis malignancy and its recurrence in Chinese women. J Obstet Gynaecol. 2019;39(8):1148-53. DOI: 10.1080/01443615.2019.1603209.

42. Pearce CL, Templeman C, Rossing MA, Lee A, Near AM, Webb PM et al. Association between endometriosis and risk of histological subtypes of ovarian cancer: a pooled analysis of case-control studies. Lancet Oncol. 2012;13(4):385-94. DOI: 10.1016/S1470-2045(11)70404-1.

43. Wang Y, Mang M, Wang Y, Wang L, Klein R, Kong B et al. Tubal origin of ovarian endometriosis and clear cell and endometrioid carcinoma. Am J Cancer Res. 2015;5(3):869-79. PMID: 26045974.

44. Wang Y, Hong S, Mu J, Wang Y, Lea J, Kong B et al. Tubal origin of "ovarian" low-grade serous carcinoma: A gene expression profile study. J Oncol. 2019;2019:8659754. DOI: 10.1155/2019/ 8659754.

45. Rhodes A, Vallikkannu N, Jayalakshmi P. Expression of WT1 and PAX8 in the epithelial tumours of Malaysian women with ovarian cancer. Br J Biomed Sci. 2017;74(2):65-70. DOI: 10.1080/09674845.2016.1220709.

46. Hatano Y, Hatano K, Tamada M, Morishige KI, Tomita H, Yanai $H$ et al. A comprehensive review of ovarian serous carcinoma, advances in anatomic pathology. 2019;26(5):329-39. DOI:10.1097/PAP.0000000000000243.

47. Sallum L, Andrade L, Ramalho S, Ferracini AC, de Andrade Natal R, Brito ABC et al. WT1, p53 and p16 expression in the diagnosis of low- and high-grade serous ovarian carcinomas and their relation to prognosis. Oncotarget. 2018;9(22):15818-27. DOI: 10.18632/oncotarget.24530.

48. Akahane T, Sekizawa A, Purwosunu Y, Nagatsuka M, Okai T. The role of p53 mutation in the carcinomas arising from endometriosis. Int J Gynecol Pathol. 2007;26(3):345-51. DOI: 10.1097/pgp.0b013e31802b41a8.

49. Ma X, Hui Y, Lin L, Wu Y, Zhang X, Qin X. Possible relevance of tumor-related genes mutation to malignant transformation of endometriosis. Eur J Gynaecol Oncol. 2016;37(1):89-94. PMID: 27048117.

50. Nahar K, Ferdous B, Akhter N, Shamsunnahar PA, Khatun K, Begum SA et al. Ovarian endometrioid adenocarcinoma arising in endometriosis: A case report. Mymensingh Med J. 2018;27(2):420-3. PMID: 29769513.

51. Bulun SE, Wan Y, Matei D. Epithelial mutations in endometriosis: Link to ovarian cancer. Endocrinology. 2019;160(3):626-38. DOI:10.1210/en.2018-00794. 


\section{Author information}

Liudmila M. Mikhaleva - Dr. Sci. (Med.), Professor, Director, Head of the Laboratory of Clinical Morphology, Research Institute of Human Morphology. https://orcid.org/0000-0003-2052-914X

Tatiana V. Bezuglova - Cand. Sci. (Biol), Deputy Director for Scientific Work, Research Institute of Human Morphology. https://orcid.org/0000-0001-7792-1594

Olga I. Patsap - Head of the Department of Pathology, Federal Center of Brain Research and Neurotechnologies. https://orcid.org/0000-0003-4620-3922

Aleksandr I. Davydov - Dr. Sci. (Med.), Professor, Professor of the Department of Obstetrics, Gynecology and Perinatology, N.V. Sklifosovsky Institute of Clinical Medicine, I.M. Sechenov First Moscow State Medical University (Sechenov University). https://orcid.org/0000-0001-5592-8429

Gjumrakch M. Aliev - Cand. Sci. (Med.), President of the GALLY International Research Institute. https://orcid.org/0000-0001-7373-3182

\section{Информация об авторах}

Людмила Михайловна Михалева - доктор медицинских наук, профессор, директор, заведующая лабораторией клинической морфологии НИИ морфологии человека.

Татьяна Васильевна Безуглова - кандидат биологических наук, заместитель директора по научной работе НИИ морфологии человека. Ольга Игоревна Пацап - заведующая патологоанатомическим отделением Федерального центра мозга и нейротехнологий.

Александр Ильгизирович Давыдов - доктор медицинских наук, профессор, профессор кафедры акушерства, гинекологии и перинатологии Института клинической медицины им. Н.В. Склифосовского Первого МГМУ им. И.М. Сеченова (Сеченовский Университет).

Гюмрах Магомедович Алиев - кандидат медицинских наук, президент Международного научно-исследовательского института GALLY. 